\title{
Żywienie drogą przewodu pokarmowego (żywienie dojelitowe)
}

\author{
Stanisław Kłęk , Jerzy Jarosz², Aleksandra Kapała ${ }^{3}$, \\ Joanna Krawczyk ${ }^{3}$, Małgorzata Misiak ${ }^{4}$, Kinga Szczepanek ${ }^{2}$, \\ Maciej Krzakowski ${ }^{2}$, Jacek Jassem ${ }^{5}$
}

Artykuł przedstawia kolejną część zaleceń dotyczących żywienia do- i pozajelitowego w onkologii. Przedstawione zostały wskazania do leczenia, metody interwencji i monitorowania oraz rodzaje diet. Jako metoda z wyboru, żywienie dojelitowe powinno zawsze być rozważane w pierwszym etapie podejmowania decyzji o leczeniu żywieniowym. Korzystny wpływ tej interwencji został udowodniony w wielu pracach naukowych.

\section{Enteral nutrition in cancer patients}

The manuscript presents the second part of recommendations on enteral and parenteral nutrition in oncology. It describes indications, methods of intervention, types of diets and techniques for monitoring. The enteral nutrition (EN) is a method of choice for nutritional support, hence it should be always considered as the first step, whenever the latter is necessary. The beneficial effect of EN was demonstrated in many clinical studies.

NOWOTWORY Journal of Oncology 2014; 64, 5: 436-442

Słowa kluczowe: żywienie kliniczne, żywienie dojelitowe, żywienia pozajelitowe

Key words: clinical nutrition, enteral nutrition, parenteral nutrition

\section{Wstęp}

Podczas uzgodnieniowej konferencji, która odbyła się w Centrum Onkologii w Warszawie w grudniu 2011 r. z inicjatywy Polskiego Towarzystwa Onkologicznego i Polskiego Towarzystwa Onkologii Klinicznej przy udziale Polskiego Towarzystwa Żywienia Pozajelitowego, Dojelitowego i Metabolizmu, panel ekspertów zadecydował o konieczności stworzenia wytycznych leczenia żywieniowego u chorych na nowotwory [1]. Wszystkie wymienione towarzystwa naukowe traktują te problemy jako ważny element leczenia wspomagającego, istotnie wpływający na jakość życia i leczenia chorych oraz na uzyskiwane wyniki leczenia przeciwnowotworowego. Potwierdzają to spostrzeżenia, że problemy żywieniowe chorych nowotworowych, chociaż rozpoznawane jako ważne, są w Polsce zaniedbane [1]. Tylko około 10\% chorych ma szansę uzyskać poradę dietetyczną lub leczenie żywieniowe. W kraju nie ma wystarczającej liczby poradni dietetycznych oraz zespołów żywieniowych przy ośrodkach onkologicznych. Problematyka żywieniowa nie znajduje odpowiedniego miejsca w szkoleniu onkologów, a udział dietetyków w systemie poradnictwa onkologicznego jest marginalizowany [1].

Niniejsze opracowanie przedstawia pierwszą część zaleceń, dotyczącą żywienia dojelitowego.

\section{Zalecenia ogólne}

Prawidłowa interwencja żywieniowa powinna składać się z następujących etapów:

\footnotetext{
${ }^{1}$ Oddział Chirurgii Ogólnej i Onkologicznej, Szpital Specjalistyczny im. Stanleya Dudricka w Skawinie ${ }^{2}$ Centrum Onkologii — Instytut im. M. Skłodowskiej-Curie w Warszawie ${ }^{3}$ Warszawski Uniwersytet Medyczny ${ }^{4}$ Oddział Intensywnej Terapii i Anestezjologii, Szpital Praski im. Przemienienia Pańskiego w Warszawie ${ }^{5}$ Gdański Uniwersytet Medyczny
}

Artykuł ten ukazuje się też w pismach Onkologia w Praktyce Klinicznej i Postępy Żywienia Klinicznego 
a) ocena stanu odżywienia i rodzaju zaburzeń,

b) ocena wskazań do leczenia i zapotrzebowania na składniki odżywcze,

c) wybór drogi interwencji: przewodu pokarmowego (czyli dojelitowa), dożylna lub mieszana,

d) przygotowanie programu żywienia,

e) podawanie składników odżywczych,

f) monitorowanie przebiegu leczenia i jego wyników [2-4].

\section{Ocena stanu odżywienia}

Cel: identyfikacja chorych zagrożonych niedożywieniem lub niedożywionych, określenie rodzaju i stopnia niedożywienia, a w późniejszym okresie także monitorowanie skuteczności leczenia żywieniowego [3,4].

Metody:

- wywiad żywieniowy;

- badania antropometryczne (aktualna masa ciała, niezamierzona utrata masy ciała, wskaźnik masy ciała do wzrostu [Body Mass Index — BMI — wartość graniczna, poniżej której należy włączyć interwencję żywieniową, to $18,5 \mathrm{~kg} / \mathrm{m}^{2}$ ], obwód ramienia, grubość fałdu nad mięśniem trójgłowym, siła uścisku dłoni, bioimpedancja);

- badania biochemiczne (stężenie w surowicy albuminy, prealbuminy, transferyny, całkowita liczba limfocytów $[\mathrm{CLL}])$;

- skale oceny stanu odżywienia (Mini Nutritional Assessment, Malnutrition Universal Screening Tool (MUST), Nutritional Risk Screening 2002 (NRS 2002) i Subjective Global Assessment (SGA)).

Od 1 stycznia 2012 r. w polskich szpitalach obowiązuje Rozporządzenie Ministra Zdrowia, zgodnie z którym należy dokonać oceny stanu odżywienia każdego pacjenta przyjmowanego do oddziału (oprócz oddziału SOR) za pomocą skali SGA lub NRS 2002 (obie skale przedstawiono w tabeli I i II).

Ocena stanu odżywienia powinna być dokonana w momencie ustalenia rozpoznania i okresowo powtarzana z uwagi na znaczne prawdopodobieństwo pogorszenia stanu odżywienia w trakcie rozwoju choroby oraz leczenia przeciwnowotworowego $[3,4]$.

\section{Określenie wskazań do leczenia żywieniowego}

W ostatnich latach wskazania do leczenia żywieniowego znacznie uproszczono, i według Europejskiego Towarzystwa Żywienia Klinicznego i Metabolizmu (European Society for Clinical Nutrition and Metabolism, ESPEN) obejmują one:

1) spodziewany brak możliwości zastosowania diety doustnej przez ponad $7 \mathrm{dni}$;

2) obecne lub zagrażające niedożywienie;

3) brak możliwości utrzymania dziennego spożycia pokarmów > 60\% zalecanej normy przez ponad 10 dni;

4) okres poprzedzający duży zabieg operacyjny z zakresu chirurgii onkologicznej w obrębie jamy brzusznej (np. pankreatoduodenektomia, gastrektomia) lub okolicy głowy i szyi - rutynowe 5-7-dniowe przedoperacyjne wsparcie żywieniowe.

Co ważne, nie ma żadnych wiarygodnych danych wskazujących na to, że leczenie żywieniowe ma wpływ na pobudzanie wzrostu nowotworu, czyli przyspieszenie rozwoju choroby, chociaż nie można wykluczyć stymulującego wpływu niektórych składników odżywczych na wzrost nowotworu [2]. Z kolei niedobór składników odżywczych w sposób oczywisty nie tylko nie hamuje rozwoju nowotworu, ale także istotnie pogarsza stan chorego, zmniejsza tolerancję leczenia onkologicznego, zwiększa ryzyko wystąpienia powikłań i może prowadzić do przerwania leczenia przeciwnowotworowego, a w skrajnych przypadkach nawet do zgonu [5-9]. Niedożywienie jest także niezależnym negatywnym czynnikiem prognostycznym i zwiększa ryzyko wystąpienia toksyczności leczenia przyczynowego [10-12].

\section{Zapotrzebowanie na składniki odżywcze}

Najważniejsze zasady

1. Dorosły człowiek powinien otrzymywać $0,8-1,5 \mathrm{~g}$ biał$\mathrm{ka} / \mathrm{kg} \mathrm{mc}$. na dobę, a jego potrzeby energetyczne wynoszą 25-35 kcal/kg mc. na dobę. Znacznie wyniszczeni chorzy powinni otrzymać 35-45 kcal/mc/dobę, w tym 2-3 g białka/kg mc. Udział poszczególnych makroskładników w zaspokajaniu potrzeb energetycznych powinien wynosić: węglowodany 35-50\%; tłuszcze 30-50\%, białko $15-20 \%[9,13,14]$.

2. Zapotrzebowanie należy obliczyć na podstawie idealnej masy ciała (najprostszy wzór na idealną masę ciała to wzrost $(\mathrm{cm})$ - 100. Dla uproszczenia można przyjąć, że w przypadku chorych o prawidłowej masie ciała i niedożywionych masa idealna jest równa masie aktualnej (czyli stwierdzonej w chwili badania).

3. Leczenie żywieniowe powinno być kompletne, gdyż jedynie wówczas będzie skuteczne. Organizm musi otrzymać wszystkie niezbędne składniki, do których należą: aminokwasy, węglowodany, tłuszcze, elektrolity $(\mathrm{Na}, \mathrm{K}, \mathrm{Ca}, \mathrm{Mg}, \mathrm{Cl}, \mathrm{P})$, pierwiastki śladowe, witaminy (retinol, kalcyferol, tokoferol, wit. K, tiamina, ryboflawina, pirydoksyna, wit. $\mathrm{B}_{12}$, kwas pantotenowy, kwas foliowy, niacyna, kwas askorbinowy) i woda.

4. Wszystkie pozostałe składniki prawidłowej diety, czyli elektrolity, witaminy i pierwiastki śladowe, powinny być podawane w ilościach pokrywających zapotrzebowanie dobowe (RDA - recommended daily allowance).

5. Warunek ten w przypadku żywienia dojelitowego jest spełniony, jeżeli stosuje się dietę przemysłową w ilości należnej na kilogram idealnej masy ciała w ciągu doby. Dobowe zapotrzebowanie na elektrolity w przeliczeniu na kg mc. przedstawia się następująco: sód 1-2 mM, potas 0,5-2 mM, wapń 0,1 mM, magnez 0,1-0,2 mM, 
Tabela I. NRS 2002 — Wstępne badanie przesiewowe

\begin{tabular}{|c|c|c|c|}
\hline \multicolumn{2}{|c|}{ Pytanie } & & Nie \\
\hline $\mathrm{BMI}<$ & \multicolumn{3}{|c|}{$\mathrm{BMI}<20,5$} \\
\hline utrata & \multicolumn{3}{|c|}{ utrata masy ciała w ciągu ostatnich 3 miesięcy } \\
\hline zmnie & \multicolumn{3}{|c|}{ zmniejszone przyjmowanie posiłków w ciągu ostatniego tygodnia } \\
\hline czy pa & \multicolumn{3}{|c|}{ czy pacjent jest ciężko chory? (np. przebywa na oddziale intensywnej opieki medycznej — OIOM) } \\
\hline \multicolumn{4}{|c|}{$\begin{array}{l}\text { Tak - w przypadku odpowiedzi twierdzącej choćby na } 1 \text { pytanie konieczne jest wykonanie kolejnego etapu badania przesiewowego przy użyciu } \\
\text { drugiej części tabeli NRS } 2002\end{array}$} \\
\hline \multicolumn{4}{|c|}{ Nie — jeżeli odpowiedź na wszystkie pytania brzmi „nie”, badanie przesiewowe należy powtórzyć po tygodniu } \\
\hline \multicolumn{4}{|c|}{ Nutritional Risk Screening 2002 (część szczegółowa)* } \\
\hline \multicolumn{2}{|c|}{ Pogorszenie stanu odżywienia } & \multicolumn{2}{|c|}{$\begin{array}{l}\text { Nasilenie ciężkości choroby (= zwiększone } \\
\text { zapotrzebowanie na składniki odżywcze) }\end{array}$} \\
\hline $\begin{array}{l}0 \text { pkt } \\
\text { brak }\end{array}$ & stan odżywienia prawidłowy & $\begin{array}{l}0 \text { pkt } \\
\text { brak }\end{array}$ & $\begin{array}{l}\text { normalne zapotrzebowanie na } \\
\text { składniki odżywcze }\end{array}$ \\
\hline $\begin{array}{l}1 \text { pkt } \\
\text { lekkie } \\
\text { niedożywienie }\end{array}$ & $\begin{array}{l}\text { utrata masy ciała }(\mathrm{mc} \text {.) }>5 \% \text { w ciągu } 3 \text { mies. lub przyjmowanie } \\
\text { pożywienia }<50-75 \% \text { zapotrzebowania w ciągu ostatniego } \\
\text { tygodnia }\end{array}$ & $\begin{array}{l}1 \text { pkt } \\
\text { lekkie niedożywienie }\end{array}$ & $\begin{array}{l}\text { złamanie kości biodrowej, } \\
\text { choroby przewlekłe z ostrymi } \\
\text { powikłaniami: marskość } \\
\text { wątroby* }{ }^{*} \text { POChP*, przewlekła } \\
\text { hemodializa, cukrzyca, choroby } \\
\text { nowotworowe }\end{array}$ \\
\hline $\begin{array}{l}2 \text { pkt } \\
\text { średnie } \\
\text { niedożywienie }\end{array}$ & $\begin{array}{l}\text { utrata mc. > 5\% w ciągu } 2 \text { mies. lub BMI 18,5- } \\
20,5 \text { z towarzyszącym pogorszeniem stanu ogólnego lub } \\
\text { przyjmowanie pożywienia w granicach } 25-60 \% \text { normalnego } \\
\text { zapotrzebowania w ciągu ostatniego tygodnia }\end{array}$ & $\begin{array}{l}2 \text { pkt } \\
\text { średnie niedożywienie }\end{array}$ & $\begin{array}{l}\text { duże operacje brzuszne*, udar } \\
\text { mózgu*, ciężkie zapalenie } \\
\text { płuc, złośliwe choroby } \\
\text { hematologiczne }\end{array}$ \\
\hline $\begin{array}{l}3 \text { pkt } \\
\text { ciężkie } \\
\text { niedożywienie }\end{array}$ & $\begin{array}{l}\text { utrata mc. > 5\% w ciągu } 1 \text { mies. (> 15\% w ciągu } 3 \text { mies.) lub } \\
\text { BMI < 18,5 z towarzyszącym pogorszeniem stanu ogólnego } \\
\text { lub przyjmowanie pożywienia w granicach 0-25\% normalnego } \\
\text { zapotrzebowania w ciągu ostatniego tygodnia }\end{array}$ & $\begin{array}{l}3 \text { pkt } \\
\text { ciężkie niedożywienie }\end{array}$ & $\begin{array}{l}\text { uraz głowy*, przeszczep } \\
\text { szpiku kostnego*, pacjenci } \\
\text { wymagający intensywnej } \\
\text { terapii* (stan oceny w skali } \\
\text { APACHE > } 10 \text { pkt) }\end{array}$ \\
\hline \multicolumn{2}{|c|}{ razem: ........ pkt } & \multicolumn{2}{|l|}{ Razem: .......pkt } \\
\hline \multicolumn{2}{|l|}{ Wiek } & \multicolumn{2}{|c|}{$\begin{array}{l}\text { jeżeli chory ma > } 70 \text { lat, dodaj } 1 \text { punkt do sumy } \\
\text { punktów }\end{array}$} \\
\hline \multicolumn{4}{|c|}{ Suma punktów: ............... } \\
\hline \multicolumn{4}{|c|}{ suma pkt > lub = 3 oznacza ryzyko niedożywienia i konieczność rozpoczęcia wspomagania (leczenia) żywieniowego } \\
\hline
\end{tabular}

*Ta część skali NRS 2002 została wybrana przez Ministerstwo Zdrowia do oceny przesiewowej przy przyjęciu do szpitala

fosfor $0,1-0,5 \mathrm{mM}$, natomiast dobowe zapotrzebowanie na wodę u dorosłego chorego nie przekracza zwykle 30-40 ml/kg mc. [15-17].

\section{Wybór drogi leczenia żywieniowego}

Wybór metody leczenia żywieniowego opiera się na analizie następujących czynników:

- stanu klinicznego chorego,

- stopnia i rodzaju niedożywienia,

- planowanego czasu żywienia,

- okresu stosowania żywienia (okres przedoperacyjny lub pooperacyjny, okres katabolizmu, rekonwalescencji).

Należy pamiętać, że metodą z wyboru jest żywienie drogą przewodu pokarmowego (synonimy: żywienie dojelitowe, żywienie enteralne, enteral nutrition).

Żywienie dojelitowe obejmuje następujące drogi podawania pokarmu:
- droga doustna (stosowanie odpowiednio zbilansowanej diety kuchennej pod kontrolą dietetyka);

- stosowanie przemysłowych płynnych diet doustnych (sip feeding, oral nutritional supplements, ONS);

- żywienie do żołądka (przy użyciu zgłębnika lub przetoki odżywczej, czyli gastrostomii);

— żywienie do jelita cienkiego (przy użyciu zgłębnika lub przetoki odżywczej, czyli jejunostomii).

Żywienie dojelitowe należy wybierać zawsze wówczas,

kiedy nie zaistnieją następujące przeciwwskazania: przeszkoda w jelitach lub niedrożność przewodu pokarmowego (porażenna lub mechaniczna), ciężki wstrząs, niedokrwienie jelit, nieustępliwe biegunki lub wymioty, ciężkie zaburzenia wchłaniania drogą przewodu pokarmowego lub przetoki przewodu pokarmowego bez możliwości wykorzystania odcinka jelita położonego poniżej przetoki w wystarczającym zakresie (np. po radioterapii). 


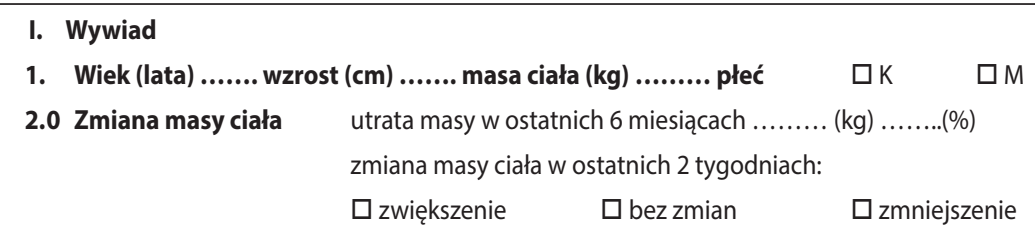

3. Zmiany w przyjmowaniu pokarmów
$\square$ bez zmian $\square$ zmiany: czas trwania .. (tygodnie)
Rodzaj diety:
$\square$ zbliżona do optymalnej dieta oparta na pokarmach stałych
$\square$ dieta płynna kompletna
$\square$ dieta płynna hipokaloryczna
$\square$ głodzenie

4.0 Objawy ze strony przewodu pokarmowego (utrzymujące się ponad 2 tygodnie)
$\square$ bez objawów
$\square$ nudności
$\square$ wymioty
$\square$ biegunka
$\square$ jadłowstręt

5.0 Wydolność fizyczna

$\square$ bez zmian $\square$ zmiany: czas trwania ........ (tygodnie)

$$
\begin{aligned}
\text { rodzaj: } & \square \text { praca w ograniczonym zakresie } \\
& \square \text { chodzi } \\
& \square \text { leży }
\end{aligned}
$$

6.0 Choroba a zapotrzebowanie na składniki odżywcze:

wzrost zapotrzebowania metabolicznego wynikające z choroby
$\square$ brak
$\square$ mały
$\square$ średni
$\square$ duży

II.0 Badania fizykalne

należy określić stopień zaawansowania:

0 - bez zmian, 1 - lekki, 2 - średni, 3 - ciężki

$\square$ utrata podskórnej tkanki tłuszczowej nad mięśniem trójgłowym i na klatce piersiowej

$\square$ zanik mięśni (czworogłowy, naramienny)

$\square$ obrzęk nad kością krzyżową

$\square$ obrzęk kostek

$\square$ wodobrzusze

III. Subiektywna globalna ocena stanu odżywienia (SGA):

$\square$ prawidłowy stan odżywienia

$\square$ podejrzenie niedożywienia lub niedożywienie średniego stopnia

$\square$ wyniszczenie

$\square$ duże ryzyko niedożywienia

U chorych ze wskazaniami do leczenia żywieniowego, u których drogą dojelitową nie można podać odpowiedniej liczby kalorii (min.60\% dziennego zapotrzebowania), należy rozważyć połączone żywienie pozajelitowe i dojelitowe.

Pierwszym etapem interwencji żywieniowej, jeśli pozwala na to stan chorego, powinna być porada dietetyczna.

\section{Poradnictwo dietetyczne}

Porada dietetyczna to pierwszy krok interwencji żywieniowej, który można zastosować prawie u wszystkich chorych. Zgodnie zzaleceniami ESPEN — u chorych onkologicznych zasadność i skuteczność stosowania poradnictwa dietetycznego ma siłę wiarygodności dowodów naukowych A według Evidence Based Medicine.
Prawidłowo zaplanowana porada dietetyczna to najbezpieczniejszy dla chorego, najprostszy i najtańszy sposób na utrzymanie i/lub poprawę stanu odżywienia. Poradnictwo dietetyczne powinno być adresowane do chorych na wszystkich etapach leczenia onkologicznego: od momentu rozpoznania - poprzez okres aktywnego leczenia, bez względu na stosowaną metodę terapii - w okresie rekonwalescencji, w profilaktyce wtórnej czy w opiece paliatywnej. Istotne jest objęcie opieką chorych po zakończonym leczeniu onkologicznym (tzw. grupy szczególne) — co prawda wolnych od nowotworu lub w okresie dłuższej remisji, ale z obecnością głębokiego niedożywienia z powodu istotnego naruszenia anatomii i/lub fizjologii przewodu pokarmowego (np. chorzy z nowotworami głowy i szyi czy górnego odcinka przewodu pokarmowego). 
Zalecenia dietetyczne zawsze muszą pokryć zapotrzebowanie chorego na podstawowe składniki diety: białko, węglowodany, tłuszcze, witaminy, minerały i wodę. W zaleceniach tych może się znaleźć dieta doustna, oparta o zwykłe produkty dostępne na rynku spożywczym, lub dieta wzbogacona (fortyfikowana) naturalnymi lub sztucznymi produktami (ONS).

Fortyfikacja żywności to sposób na zwiększenie wartości odżywczej diety poprzez:

1) dodawanie produktów naturalnych o dużej gęstości kalorycznej (np. masło, śmietanka, cukier, miód, żółtko jaja, oleje roślinne, mleko kokosowe, gęste kasze, zmielone orzechy, mięso itp.);

2) dodawanie przemysłowo produkowanych preparatów jedno- lub wieloskładnikowych.

Fortyfikowanie żywności poprzez produkty naturalne czy przemysłowe powinno być zawsze nadzorowane poprzez wykwalifikowanego dietetyka.

\section{Doustne suplementy pokarmowe (doustne diety przemysłowe)}

Preparaty typu ONS to specjalna kategoria żywności medycznej służąca żywieniowemu wsparciu pacjentów niedożywionych lub zagrożonych niedożywieniem pod nadzorem wykwalifikowanego personelu medycznego (dyrektywa Unii Europejskiej 1999/21/EC 25.03.1999) [18]. Do prowadzenia nadzoru medycznego nad stosowaniem ONS (zlecanie i monitorowanie efektu ich działania) uprawnieni są lekarze, dietetycy, farmaceuci i specjalnie wykwalifikowane pielęgniarki.

Preparaty typu ONS mogą być niekompletne i kompletne pod względem składu (zawierają tylko wybrane lub wszystkie makro-i mikroskładniki diety). Wyróżnia się preparaty standardowe (odzwierciedlające skład i proporcje zwykłej diety doustnej) lub preparaty specjalne (produkowane wg wymagań żywieniowych wynikających z określonych chorób - cukrzycy, niewydolności nerek etc.). ONS mogą stanowić uzupełnienie codziennej diety, a niektóre z nich mogą ją całkowicie zastąpić.

Podstawowe zalety ONS to:

1) skoncentrowane źródło kalorii i składników odżywczych w małej objętości;

2) wygoda stosowania: zbilansowany preparat gotowy do użycia, niewymagający skomplikowanych czynności kulinarnych — można go dowolnie mieszać z produktami naturalnymi, schładzać, delikatnie podgrzewać;

3) możliwość dostosowania składu preparatu do wymagań żywieniowych, jakie dyktuje choroba, np. preparaty niskobiałkowe dla chorych z niewydolnością nerek w fazie przeddializacyjnej etc.;

4) ONS nie zawierają składników potencjalnie szkodliwych (laktoza, gluten, puryny, cholesterol). W zależności od wskazań klinicznych istnieje możliwość wyboru preparatu z błonnikiem lub bez błonnika;

5) ONS pakowane są w atmosferze jałowej (sterylizowane UHT), co oznacza, że preparaty te są wolne od bakterii. Preparaty typu ONS są wskazane u każdego chorego, u którego nie można za pomocą zwykłej diety pokryć indywidualnego zapotrzebowania na składniki pokarmowe, a funkcja połykania jest sprawna.

Skuteczność stosowania ONS u chorych na nowotwory potwierdzają wyniki licznych badań, w tym metaanalizy Baldwina i wsp. oraz Milne'a i wsp. [19, 20].

W onkologii w zdecydowanej większości wykorzystuje się diety polimeryczne (zawierają cząsteczki białek i polipeptydy, maltodekstryny i kwasy tłuszczowe oraz dodatki witaminowe i mineralne). Rzadko istnieją wskazania do stosowania diet oligomerycznych (zespoły złego wchłaniania, żywienie zgłębnikiem do jelita cienkiego). Diety te charakteryzuje wyższy stopień hydrolizy cząsteczek białkowych - do krótkich peptydów. Diety monomeryczne (zawierające pojedyncze aminokwasy) praktycznie nie są stosowane w onkologii; znajdują one zastosowanie wyłącznie w rzadkich wrodzonych chorobach szlaków metabolicznych.

Na podstawie kaloryczności wyróżnia się następujące diety:

- hipokaloryczne $(0,5-0,9 \mathrm{kcal} / \mathrm{ml}$ diety);

- izokaloryczne (1-1,2 kcal/ml diety);

- hiperkaloryczne (1,3-2,4 kcal/ml diety).

Najczęściej stosowane są diety izokaloryczne.

\section{Żywienie drogq sztucznq (zgłębnik lub przetoka odżywcza)}

Wskazania: brak możliwości użycia fizjologicznej drogi naturalnej (doustnej).

Żywienie przez zgłębnik jest wskazane w sytuacji, kiedy niemożliwe jest połykanie (np. zaawansowane nowotwory głowy, szyi i przełyku czy nasilony stan zapalny błon śluzowych przewodu pokarmowego).

W żywieniu dojelitowym przez zgłębniki stosuje się diety przemysłowe, różniące się wielkością cząsteczek makroskładników odżywczych. Z uwagi na wielkość cząstek peptydowych dzielą się one na diety polimeryczne, oligomeryczne i monomeryczne.

U większości chorych wystarczające jest stosowanie diety standardowej.

U chorych, którzy nie wymagają leczenia na oddziale intensywnej terapii, ale mają wskazania do długotrwałego żywienia przez przewód pokarmowy lub maja zaparcia, można zastosować dietę bogatowłóknikową, zawierającą włókna pęczniejące i ulegające fermentacji.

Zastosowanie specjalnych diet można rozważyć w następujących przypadkach:

- diety immunomodulujące (arginina, kwasy tłuszczowe $\omega-3$ oraz nukleotydy) w okresie okołooperacyjnym 
u chorych niedożywionych lub - bez względu na stan odżywienia - u chorych poddawanych rozległym zabiegom z powodu nowotworu w górnym odcinku układu pokarmowego (resekcja przełyku, żołądka oraz pankreatoduodenektomia) oraz w obrębie głowy i szyi [1, 2];

- diety cukrzycowe, szczególnie nowej generacji (zawierające MUFA, low carbohydrate-high MUFA - LCHM) - wskazaniem do ich stosowania jest sytuacja, gdy u chorego leczonego z powodu cukrzycy występują trudności w kontroli glikemii lub insulinooporność.

Wybór dostępu zależny jest od:

1) miejsca dostępu:żołądek lub pierwsza/druga pętla jelita;

2) czasu używania dostępu: $<2-3$ tygodnie lub $>2-3$ tygodnie.

W przypadku gdy istnieje dostęp do żołądka:

a) czas używania < 2-3 tygodnie - zgłębnik nosowo-żołądkowy;

b) czas używania > 2-3 tygodnie - gastrostomia (endoskopowa, chirurgiczna lub laparoskopowa).

Metoda z wyboru: endoskopowa (przezskórna endoskopowa gastrostomia, PEG).

W przypadku gdy nie ma dostępu do żołądka:

a) czas używania < 2-3 tygodnie - zgłębnik nosowo-jelitowy (poza więzadło Treitza lub poniżej ostatniego zespolenia jelitowego);

b) czas używania > 2-3 tygodnie - jejunostomia (endoskopowa, chirurgiczna lub laparoskopowa).

Metoda z wyboru: mikrojejunostomia.

Podczas żywienia dojelitowego należy stosować jedynie diety przemysłowe. Należy pamiętać, że żywienie za pomocą diet kuchennych jest nie tylko trudniejsze i narażone na więcej błędów, ale również nie jest refundowane przez Narodowy Fundusz Zdrowia.

\section{Sposób podawania}

Żywienie dożołądkowe może być prowadzone następującymi metodami:

- metoda bolusów - podawanie 5-6 razy w ciągu dnia porcji po 200-300 ml pod kontrolą zalegania żołądkowego (kontrola poprzez aspirację treści zżołądka przy użyciu strzykawki). Jeżeli wynosi ono ponad $200 \mathrm{ml}$, należy odstąpić od podania porcji, skontrolować ponownie, ewentualnie po wykluczeniu zaburzeń mechanicznych rozważyć zastosowania leków propulsywnych;

- metoda mikrobolusów - podawanie porcji po 50-100 ml, również pod kontrolą zalegania żołądkowego;

- wlew ciągły - prowadzony grawitacyjnie lub przy użyciu pompy żywieniowej (w tempie najczęściej 30$-50 \mathrm{ml} /$ godzinę).
Żywienie dojelitowe (poza więzadło Treitza lub poniżej ostatniego zespolenia jelitowego):

- metoda wlewu ciągłego (grawitacyjnie lub przy użyciu pompy).

\section{Leczenie wspomagające}

Ze względu na złożony mechanizm niedożywienia w chorobie nowotworowej osiągnięcie stanu anabolizmu jest bardzo trudne, a wpływ żywienia na poprawę parametrów biochemicznych i klinicznych może być ograniczony. W takich sytuacjach, oprócz leczenia żywieniowego, zalecana jest farmakoterapia, której celem jest zmniejszenie odpowiedzi zapalnej. Omówienia tematu leczenia wspomagającego przekracza tematykę niniejszego opracowania.

Konflikt interesu: nie zgłoszono

Dr hab. n. med. Stanisław Kłęk

Oddział Chirurgii Ogólnej i Onkologicznej

Szpital Specjalistyczny im. Stanleya Dudricka

ul. Tyniecka 15, 32-050 Skawina

e-mail:klek@poczta.onet.pl

Otrzymano: 7 stycznia $2014 \mathrm{r}$.

Przyjęto do druku: 4 września 2014 r.

\section{Piśmiennictwo}

1. Jarosz J, Kapała A, Kłęk Si wsp. Konferencja Uzgodnieniowa: Problemy żywieniowe w polskiej onkologii. Post Żyw Klin 2012; 1: 29-38.

2. Bozzetti F, Mori V. Nutritional support and tumour growth in humans: A narrative reviev of the literature. Clin Nutr 2009; 28: 226-230.

3. Pertkiewicz M i wsp (red.). Standardy żywienia pozajelitowego i dojelitowego. PZWL:Warszawa, 2005.

4. Lochs H, Allison SP, Meier R i wsp. Introductory to the ESPEN Guidelines on Enteral Nutrition:Terminology, definitions and general topics. Clin Nutr 2006; 25: 180-186.

5. Dewys WD, Begg C, Lavin PT i wsp. Estern Cooperative Oncology Groupe. Prognostic effect of weight loss prior to chemotherapy in cancer patients. Am J Med 1980; 69: 491-497.

6. Chute CG, Greenberg ER, Baron J i wsp. Presenting conditions of 1539 population-based lung cancer patients by cell type and stage in New Hampshire and Vermont. Cancer 1985; 56: 2107-2111.

7. Wigmore SJ, Plester CE, Richardson RA i wsp. Changes in nutritional status associated with unresectable pancreatic cancer. Br J Cancer 1997; 75: 106-109.

8. Andreyev HJ, Norman AR, Oates J i wsp. Why do patients with weight loss have a worse outcome when undergoing chemotherapy for gastrointestinal malignancies? Eur J Cancer 1998; 34: 503-509.

9. Podstawyżywienia klinicznego. Sobotka L (red.). PZWL:Warszawa, 2007.

10. Asher V, Lee J, Bali A. Preoperative serum albumin is an independent prognostic predictor of survival in ovarian cancer. Med Oncol 2012; 29: 2005-2009.

11. Bachmann J, Heiligensetzer M, Krakowski-Roosen H i wsp. Cachexia worsens prognosis in patients with resectable pancreatic cancer. J Gastrointest Surg 2008; 12: 1193-1201.

12. Arrieta $\mathrm{O}$, Michel Ortega RM, Villanueva-Rodríguez G i wsp. Association of nutritional status and serum albumin levels with development of toxicity in patients with advanced non-small cell lung cancer treated with paclitaxel-cisplatin chemotherapy: a prospective study. BMC Cancer 2010; 10: 50.

13. Zasady diagnostyki i chirurgicznego leczenia nowotworów w Polsce. Szawłowski AW, Szmidt J (red.). Fundacja-Polski Przegląd Chirurgiczny, Warszawa, 2003.

14. Bozzetti F, Arends J, Lundholm K i wsp. ESPEN Guidelines on Parenteral Nutrition: non-surgical oncology. Clin Nutr 2009; 28: 445-454. 
15. Arends J, Bodoky G, Bozzetti F i wsp. ESPEN Guidelines on Enteral Nutrition: Non-surgical oncology. Clin Nutr 2006; 25: 245-259.

16. Weimann A, Braga M, Harsanyi L i wsp. ESPEN Guidelines on Enteral Nutrition: Surgery including organ transplantation. Clin Nutr 2006; 25:224-244.

17. Braga M., Ljungqvist O, Soeters P i wsp. ESPEN Guidelines on Parenteral Nutrition: surgery. Clin Nutr 2009; 28: 378-386.

18. Commission Directive 1999/21/EC of 25. March 1999 on dietary foods for special medical purposes. http://eur-lex.europa.eu/LexUriServ/Lex-
UriServ.do?uri=CONSLEG: 1999L 0021:20070119:EN:pdf. Dostep z dnia 03.01.2014.

19. Baldwin C, Parsons T, Logan S. Dietary advice for illness-related malnutrition in adults. Cochrane Database of Syst Rev 2001; 2: CD002008.

20. Milne AC, Potter J, Vivanti A i wsp. Protein and energy supplementation in elderly people at risk from malnutrition. Cochrane Database Syst Rev 2009; 15: CD003288. 